\title{
Allelopathic Potential Assessment of Sorghum and Sunflower on Germination Characteristics of Phalaris minor and Wheat
}

\author{
Arya Kumar Sarvadamana*, V. Pratap Singh, S. K. Guru, S. P. Singh, \\ Tej Pratap, Sirazuddin and Suprava Nath
}

Department of Agronomy, G. B. Pant University of Agriculture \& Technology, Pantnagar, India

*Corresponding author

\begin{tabular}{|l|}
\hline Ke y w o r d s \\
Aqueous extract, \\
Allelopathy, \\
Germination \\
percent, Sorghum, \\
sunflower
\end{tabular}

A laboratory experiment was conducted to assess the allelopathic effect of aqueous extracts of sorghum and sunflower on germinating seedlings of Phalaris minor and wheat. 10\% (w/v) aqueous extracts of sorghum and sunflower were applied on the seed of Phalaris minor and wheat and the parameters like germination percent, relative germination ratio, speed of germination, mean germination time, days to $50 \%$ germination were calculated. In all the calculated parameters it was found that the aqueous extracts of both sorghum and sunflower are highly allelopathic to Phalaris minor and they have a very little effect on wheat. Both sorghum and sunflower aqueous extracts significantly reduced the germination of Phalaris minor as compared to control (distilled water), but sunflower was more allelopathic than sorghum with $85.5 \%$ of germination inhibition.

\section{Introduction}

Wheat is the most important cereal crop of the world and the second most important in India having 30.17 million hectare area and 99.70 million tonnes of production (Anonymous, 2018). It has a lion share of about $35 \%$ in national food basket. Wheat is a very rich source of nutrients, which have $76 \%$ carbohydrate, $1.5 \%$ fat and $13 \%$ protein. Albumins, globulins are the major proteins of the gluten complex. The contents of minerals and of dietary fibers are very low; $0.5 \%$ and $1.5 \%$, respectively (Belderok et al., 2000). Rice-wheat cropping system is the most dominant cropping system of India. In RiceWheat cropping system along with other traditional weed flora Phalaris minor became a major problem causing drastic reduction in wheat yield (Chhokar et al., 2006). Wheat fields in Northern India are badly infested with wide range of grassy and non grassy weeds in general and Phalaris minor Retz. in particular. Continuous application of herbicides at suboptimal dose, 
Phalaris minor gradually developed resistance against these (Chhokar and Malik, 2002). Hence, to tackle this problem alternative weed control methods like allelopathic approach can be a potential tool in future.

\section{Materials and Methods}

The laboratory experiment was conducted in seed physiology laboratory, Department of Agronomy, Collage of Agriculture, Govind Ballabh Pant University of Agriculture and Technology, Pantnagar, Udham Singh Nagar, Uttarakhand. Sorghum and sunflower biomass was collected from the Norman E. Borlaug Crop Research Centre, Govind Ballabh Pant University of Agriculture and Technology, Pantnagar and were shade dried for about one week at Weed management block (D2). Then the biomass of sorghum and sunflower shade dried at $65 \pm 5{ }^{\circ} \mathrm{C}$ for 72 hours and finely ground with an electric grinder after fully drying. The grinded biomass was placed in an air tight container in cool and dry place. The ground biomass was weighed using high precision electronic balance. After this the grinded biomass was well mixed in distilled water and soaked for 48 hours in refrigerator to avoid fermentation. This was then filtered using muslin cloth to get aqueous extract. Using this method aqueous extracts of sorghum and sunflower of $10 \%$ concentration (w/v, dry weight basis) was prepared.

The experiment was carried out in Completely Randomized Design (CRD), with three treatments i.e. control (distilled water), 10\% aqueous extract of sorghum, $10 \%$ aqueous extract of sunflower, each with three replications.

Healthy, disease free and uniform seeds of both wheat (variety-DBW 17) and Phalaris minor were collected and treated with thiram to avoid fungal infection. Petridishes with $15 \mathrm{~cm}$ diameter was also taken and cleaned properly with chromic acid to remove all the dirt adhering with it. Then it was washed with distilled water and put in hot air oven for drying. After the drying is completed the petridishes were sterilized with methanol.

On the bottom side of petridish two filter papers were put to hold the aqueous extract. Then 50 seeds were arranged uniformly on the filter paper and $5 \mathrm{ml}$ aqueous extract was added to each petridish with help of pipette.

Finally the pertidishes were put in a seed incubator at $25 \pm 1{ }^{\circ} \mathrm{C}$ for 7 days for the germination procedure to be completed.

The parameters were calculated as the formula given below-

Germination percent (AOSA, 1998)

$=\frac{\text { No. of seeds produced normal seedlings }}{\text { No of seedlings set for germination }} \times 100$

Relative germination ratio (Rho and Kill,1986)

$=\frac{\text { germination percent of treated seeds }}{\text { germination percent of control }} \times 100$

Speed of germination (AOSA,1983)

$=\frac{\text { No. of seedlings }}{\text { Day of 1st count }}+--------+\frac{\text { No.of seedlings }}{\text { Day of final count }}$

Mean germination time (Bonner, 1983)

$=\frac{\sum\left(n \times d_{i}\right)}{\text { No. of seeds set for germination }}$

Where,

$\mathrm{n}=$ number of seeds newly germinated on day di

$\mathrm{di}=\mathrm{i}^{\text {th }}$ day after incubation

Days to $50 \%$ germination (Dezfuli et al.,2008)

$=t i+\frac{[(N / 2)-n i] \times(t i-t j)}{(n i-n j)}$ 
$\mathrm{T} 50=t i+\frac{\{(N / 2)-n i\} \times(t i-t j)}{(n i-n j)}$

Where,

$\mathrm{N}=$ final number of germinated seeds

ni and $\mathrm{nj}$ are cumulative number of seeds germinated by adjacent counts at times ti and $\mathrm{tj}$, where $\mathrm{ni}<\mathrm{N} / 2<\mathrm{nj}$

\section{Results and Discussion}

\section{Germination per cent (7 days after incubation)}

The germination per cent of wheat was found non significant between the treatments, which is a desirable character. But, numerically maximum germination percent was found in case of control and extract of sunflower (96.00\%). However, minimum (94.0\%) was achieved by the application of extract of sorghum at $10 \%$ (Table 1).

The germination per cent Phalaris minor was found highest in control $(82.66 \%)$. In case of aqueous extract of sunflower lowest germination percent of Phalaris minor was found $(12 \%)$, which is significantly lower than both control and aqueous extract of sorghum at same concentration. The application of aqueous extract at 10 percent concentration reduced the population of Phalaris minor by $85.4 \%$ and $42.7 \%$ under sunflower and sorghum extracts respectively with respect to control.

It is evident that sorghum and sunflower extracts have strong allelopathic effect on Phalaris minor but little allelopathic effect on wheat. It also matches with the findings of Anjum and Bajwa (2005).

Among sorghum and sunflower, sunflower has higher inhibitory effect on Phalaris minor and it also does not affect germination of wheat, there by fulfilling our aim. Hence, sunflower aqueous extract can be used as a potential tool for Phalaris minor control in wheat.

Based on this findings a field experiment was also conducted by the sequential (pre $f b$ early post) application of both the aqueous extracts of sorghum and sunflower at same concentration $(10 \%)$.

\section{Relative germination ratio}

Relative germination ratio gives information about germination percent of all the treatments in comparison to control. In wheat relative germination ratio was found non-significant among the treatments.

It shows that all the treatments are alike with respect to their percentage of germination. This gives an idea that the allelochemicals present in sorghum and sunflower don't check germination of wheat seeds. But, while the Phalaris minor seeds lowest germination ratio was obtained with aqueous extract of sunflower treated seeds (14.5) followed by aqueous extract of sorghum treated seeds (57.16).

This type of result comes due to a little allelopathic effect of sorghum and sunflower on wheat and a very high allelopathic effect on Phalaris minor seeds. This type of result matches with the study of Bhadoria, (2011).

\section{Speed of germination}

The aqueous extract of sorghum as well as sunflower had no effect on the speed of germination $f$ wheat.

However, in case of Phalaris minor the minimum speed was recorded with application of aqueous extract of sunflower (10\%), which was significantly lower than the aqueous extract of sorghum (10\%) (Table 2). 
Table.1 Effect of aqueous extracts of sorghum and sunflower (10\%) on germination percent and relative germination ratio of wheat and Phalaris minor

\begin{tabular}{|l|l|l|l|l|}
\hline \multirow{2}{*}{ Treatment } & \multicolumn{2}{|l|}{ Germination percent $\mathbf{( \% )}$} & \multicolumn{2}{l|}{ Relative germination ratio } \\
\cline { 2 - 5 } & Wheat & Phalaris minor & Wheat & Phalaris minor \\
\hline $\begin{array}{l}\text { Control } \\
\text { (distilled water) }\end{array}$ & 96.00 & 82.66 & 100 & 100 \\
\hline Sorghum (10\%) & 94.00 & 47.33 & 97.74 & 57.16 \\
\hline $\begin{array}{l}\text { Sunflower } \\
(\mathbf{1 0 \%})\end{array}$ & 96.00 & 12.00 & 99.55 & 14.5 \\
\hline SEm \pm & 0.94 & 1.30 & 1.50 & 1.35 \\
\hline CD $(\mathbf{5 \% )}$ & NS & 4.50 & NS & 4.77 \\
\hline
\end{tabular}

Table.2 Effect of aqueous extracts of sorghum and sunflower (10\%) on Speed of germination, Mean germination time and Days to $50 \%$ germination of wheat and Phalaris minor

\begin{tabular}{|c|c|c|c|c|c|c|}
\hline \multirow[t]{2}{*}{ Treatment } & \multicolumn{2}{|c|}{$\begin{array}{l}\text { Speed of germination (no.of } \\
\text { seedlings germinated/ day) }\end{array}$} & \multicolumn{2}{|c|}{$\begin{array}{l}\text { Mean germination } \\
\text { time (days) }\end{array}$} & \multicolumn{2}{|c|}{$\begin{array}{l}\text { Days to } 50 \% \\
\text { germination }\end{array}$} \\
\hline & Wheat & $\begin{array}{l}\text { Phalaris } \\
\text { minor }\end{array}$ & Wheat & $\begin{array}{l}\text { Phalaris } \\
\text { minor }\end{array}$ & Wheat & $\begin{array}{l}\text { Phalaris } \\
\text { minor }\end{array}$ \\
\hline $\begin{array}{l}\text { Control } \\
\text { (distilled } \\
\text { water) }\end{array}$ & 6.9 & 5.9 & 5.34 & 3.36 & 3.12 & 4.25 \\
\hline $\begin{array}{l}\text { Sorghum } \\
(\mathbf{1 0 \% )}\end{array}$ & 6.73 & 3.38 & 5.22 & 1.89 & 3.17 & 4.31 \\
\hline $\begin{array}{l}\text { Sunflower } \\
(10 \%)\end{array}$ & 6.83 & 1.57 & 5.47 & 0.54 & 3.13 & 4.29 \\
\hline SEm \pm & 0.06 & 0.08 & 0.05 & 0.02 & 0.04 & 0.07 \\
\hline CD $(5 \%)$ & NS & 0.30 & 0.18 & 0.08 & NS & NS \\
\hline
\end{tabular}

While both the aqueous extracts were Mean germination time significantly superior over control.

It is obvious that aqueous extract of sunflower $(10 \%)$ has a inhibitory effect on the germination of Phalaris minor.

This finding are in agreement with the reports of Ghafar et al., (2001), who stated that five allelochemicals like (chlorogenic, caffeic, syringic, vanillic and ferulic acid) in leaves, three allelochemicals in stem (chlorogenic, ferulic and vanillic acids) and only one (ferulic acid) in the roots have allelopathic effect on Phalaris minor.

The mean germination time of wheat in aqueous extract of sunflower $10 \%$ (5.47) is statistically at par with control (5.34), however it was significantly higher than aqueous extract of sorghum 10\% (5.22). The mean germination time of Phalaris minor was found significantly lower by the application of both the aqueous extract of sorghum (1.89) and sunflower (0.54) than control (3.36).

This results reveals that sunflower has a lesser inhibitory effect on wheat followed by sorghum extract, and a very strong 
allelopathic effect on Phalaris minor. Hence, it may be concluded that sunflower can be a potential source in managing Phalaris minor in wheat crop.

\section{Days to $50 \%$ germination $\left(\mathrm{T}_{\mathbf{5 0}}\right)$}

Days to $50 \%$ germination was found non significant over the treatments on both wheat and Phalaris minor. But numerically it was found higher in aqueous extract of sorghum $10 \%$ (4.31) on Phalaris minor. This might be due to the allelo-chemicals affect the germination process uniformly throughout the germination period.

\section{References}

Anjum, T. and Bajwa, R. 2005 A bioactive annuionone from sunflower leaves. Phytochem 66: 1919-1921.

Anonymous. 2018. Agricultural Statistics at a Glance-2016.Directorate of Economics and Statistics, Ministry of Agriculture, Govt. Of India.

Association of Official Seed Analysis (AOSA) 1983.Seed vigor testing handbook, Contribution No. 32 to the Handbook of seed testing.

Association of Official Seed Analysis (AOSA) 1998.Rules of testing seeds. Journal of Seed Technology. 12: 1-112.

Belderok, B.; Mesdag, H. and Donner, D.A.
2000. Bread-Making Quality of Wheat. Springer, New York.

Bonner, F.T. 1983. Germination responses of loblolly pine to temperature differences on a two-day thermogradient plate. $J$. Seed Technol., 8(1): 6-14.

Chhokar, R.S. and Malik, R.K. 2002. Isoproturon resistant Phalaris minor and its response to alternate herbicides. Weed Technology. 16: 116-123.

Chhokar, R.S.; Sharma, R.K.; Chauhan, D.S. and Mongia, A.D. 2006. Evaluation of herbicides against Phalaris minor in wheat in north western plains. Weed Research. 46: 40-49.

Dezfuli, P.M.; Sharif-zadeh, F. and Janmohannadi, M. 2008. Influence of priming techniques on seed germination behavior of maize inbreed lines (Zea mays L.) ARPN Journal of Agriculture and Biological Science, 3(3): 22-25.

Ghafar.A; Saleem.B.; Haq.A. andQureshi, M.J. 2001.Isolation and identification of allelochemicals of sunflower (Helianthus annuus L.). Int J Agric. Biol., 3: 21-22.

Rho, B.J. and Kill, B.S. 1986. Influence of phytotoxin from Pinusrigida on the selected plants. Journal of Natural Science. Wankwang university. 5:1927.

\section{How to cite this article:}

Arya kumar Sarvadamana, V. Pratap Singh, S. K. Guru, S. P. Singh, Tej Pratap, Sirazuddin and Suprava Nath. 2019. Allelopathic potential assessment of sorghum and sunflower on germination characteristics of Phalaris minor and wheat. Int.J.Curr.Microbiol.App.Sci. 8(10): 256-260. doi: https://doi.org/10.20546/ijcmas.2019.810.026 